\title{
Correction to: Supramolecular associations between atypical oxidative phosphorylation complexes of Euglena gracilis
}

\author{
H. V. Miranda-Astudillo ${ }^{1,2} \cdot$ K. N. S. Yadav ${ }^{3,4}$ - E. J. Boekema ${ }^{3}$ - P. Cardol ${ }^{1}$
}

Published online: 7 May 2021

(C) Springer Science+Business Media, LLC, part of Springer Nature 2021

\section{Correction to: Journal of Bioenergetics and Biomembranes. https://doi.org/10.1007/s10863-021-09882-8}

The original version of this article unfortunately a mistake. Table 1 should not be included in the proofs.

The original article has been corrected.

Open Access This article is licensed under a Creative Commons Attribution 4.0 International License, which permits use, sharing, adaptation, distribution and reproduction in any medium or format, as long as you give appropriate credit to the original author(s) and the source, provide a link to the Creative Commons licence, and indicate if changes were made. The images or other third party material in this article are included in the article's Creative Commons licence, unless indicated otherwise in a credit line to the material. If material is not included in the article's Creative Commons licence and your intended use is not permitted by statutory regulation or exceeds the permitted use, you will need to obtain permission directly from the copyright holder. To view a copy of this licence, visit http://creativecommons.org/licenses/by/4.0/.

Publisher's note Springer Nature remains neutral with regard to jurisdictional claims in published maps and institutional affiliations.

The online version of the original article can be found at https://doi.org/ 10.1007/s10863-021-09882-8

H. V. Miranda-Astudillo

hmiranda@iibiomedicas.unam.mx

P. Cardol

pierre.cardol@uliege.be

1 InBios/Phytosystems, Institut de Botanique, University of Liège, Liège, Belgium
2 Present address: Departamento de Biología Molecular y Biotecnología, Instituto de Investigaciones Biomédicas, Universidad Nacional Autónoma de México, Mexico City, Mexico

3 Department of Electron Microscopy, Groningen Biological Sciences and Biotechnology Institute, University of Groningen, Groningen, the Netherlands

4 Present address: School of Biochemistry, University of Bristol, Bristol BS8 1TD, UK 